\section{Journal of Educational Sciences}

Journal homepage: https://ejournal.unri.ac.id/index.php/JES

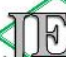

\title{
Improvement of Teacher Capability Using Contextual Teaching and Learning Models Through in House Training
}

Suhelmidam*

Head of SMP N 6 Tualang, Siak Regency, Indonesia

\section{ARTICLE INFO}

\section{Article history:}

Received: 13 July 2019

Revised: 22 Aug 2019

Accepted: 28 Aug 2019

Published online: 24 Sept 2019

Keywords:

Contextual teaching and Learning

In-House Training

\begin{abstract}
A B S T R A C T
The learning process at SMP N 6 Tualang is not satisfactory due to the relatively low teacher's competence. Therefore it is necessary to improve teacher quality. The improvement made is the ability to use the learning model. One of them is the use of the Contextual Teaching and Learning (CTL) model through In-House Training (IHT) activities. The purpose of this study is to describe and explain how effective the In House Training activities for improving teacher skills in the application of the CTL model. This study involved all teachers of SMP N 6 Tualang. The researcher conducted a pre-survey to find out the learning process in the classroom. Observation, Pre-test and interview techniques were also used to collect data. Each cycle's pre-test and post-test showed better improvement in the teacher's ability to apply this model. The teacher's assessment in designing the lesson plan learning model CTL in cycle 1 shows the average teacher's ability of $75.62 \%$ (good), in the second cycle it becomes $90.57 \%$ (very good). The results of supervision from $70.05 \%$ (good) in cycle 1 , to $82.40 \%$ (good) in cycle 2 , and teachers felt positive benefits from IHT activities. In conclusion, IHT activities were able to improve teacher competence using the CTL learning model.
\end{abstract}

\section{Introduction}

Quality learning carried out by teachers is resulted from a quality process, thus providing an opportunity to leverage the potential of students (Leonard, 2013). In general, teachers have not implemented quality learning as expected. Teachers have

\footnotetext{
* Corresponding author. Tel./Fax.: +6281365274929

E-mail: helmikudang2@gmail.com
} 
not been creative in using learning models and new approach techniques that make the classroom atmosphere more conducive and enjoyable. In addition, teachers in the average class have not empowered quality strategies and teaching arts. It has not been able to create a lively and pleasant classroom atmosphere. Based on the results of supervision carried out by the principal of SMP N 6 Tualang, it was concluded that the majority of teachers still dominated the lectures, tending to be the teacher center of the student center. Even teachers do not use the RPP they make themselves, instead they tend to use RPPs taken online that are always not in accordance with the conditions and characteristics of their students.

Even more important is that the teacher has not implemented meaningful learning, namely learning emphasized in learning with the $5 \mathrm{M}$ concept; students are directed to be active, and the teacher directs so that the knowledge acquired is not from memorizing, but from a search process and finding out for themselves about that knowledge (NCTM, 2000).

Judging from the results of the 2016/2017 class monitoring and supervision that the teacher's ability to carry out the learning process in the classroom has an average of $75 \%$ ("sufficient" category). Likewise the ability of teachers to make learning scenarios. the average teacher's ability to make lesson plans based on learning Contextual Teaching and Learning is very low. Therefore, the researcher as the principal has made gradual improvement efforts to achieve the learning process expected by the school.

Based on the above conditions, the researcher as Principal seeks that all teachers in implementing learning using the learning model, in accordance with the provisions in the Process Standards in Permendikbud No. 22 of 2016. The provision is a guideline that must be realized in the learning process in the classroom. The learning process in educational units is held in an interactive, inspirational, fun, challenging, motivating educator to actively participate, and provide sufficient space for initiatives, creativity, and independence in accordance with the talents, interests and physical and psychological development of students. For this reason, each education unit conducts learning planning, implements the learning process and evaluates the learning process to improve the efficiency and effectiveness of graduates' competencies (Permendikbud, 2016; standard process of primary and secondary education)

Contextual Teaching and Learning (CTL) is defined as a way to introduce content using a variety of activation techniques designed to help students connect what they already know to what they expect to learn, and to build new knowledge from this analysis and synthesis. learning process. The theoretical basis for CTL is described, focusing on Connections, Constructivist, and Active Learning theories (Hudson et al., 2013). According to Sanjaya (2009) it is said that the Contextual Teaching and Learning model consists of 7 components which underlie the implementation of the learning process using the Contextual Teaching and Learning model, namely constructivism, inquiry, questions, the learning community, modeling, reflection and assessment. The ability of the teacher is expected to be able to implement the Contextual Teaching and Learning learning model through clinical supervision 
conducted by the principal in the In House Training activity, with guidance, direction and high awareness capable of conducting quality learning, so that it positively influences the behavior of students and increases their learning progress.

The findings of the research on the effectiveness of the In House Training activities showed the success of IHT in increasing the ability of SDN teachers in Salatiga to develop learning media by $13.4 \%$ and in preparing lesson plans by $31.7 \%$ (Scholaria, 2016). While Faddilaturrahmi (2016) states that there is an increase in student learning outcomes seen in the aspects of cognitive, affective and psychomotor aspects through the Contextual Teaching and Learning approach.

With the abilities and skills of the teachers in compiling a Learning Implementation Plan A good CTL Model will have a positive impact on the learning process, and material targets in Core Competencies and Basic Competencies can be achieved. In addition, the creativity of teachers to form small groups in learning can foster motivation and enthusiasm for children's learning, able to foster students' creativity so that the learning can be meaningful for students (Scholaria, 2016).

The purpose of this study is to describe and explain how effective the In House Training activities for improving teacher skills in the application of Contextual Teaching and Learning learning models.

\section{Methodology}

This School Action Research was conducted at SMP N 6 Tualang, Siak Regency, Indonesia. This research was conducted during the first semester of 2017-2018. The detailed research agenda for the collecting and analizing data can be seen in Table 1.

Table 1. Research Agenda

\begin{tabular}{|c|c|c|c|}
\hline No. & Agenda & Implementation date & \\
\hline 1 & Meeting Building Commitment & 31 August 2017 & \multirow{4}{*}{ Research Preparation } \\
\hline 2 & Identification of problems & 31 August 2017 & \\
\hline 3 & $\begin{array}{l}\text { Discussion on Problem } \\
\text { Determination }\end{array}$ & 31 August 2017 & \\
\hline 4 & Making Activity Proposal & 31 August 2017 & \\
\hline 5 & Determination of Action Plans & 2 Sept-30Sept 2017 & \multirow{4}{*}{ Implementation of Research } \\
\hline 6 & $\begin{array}{l}\text { Implementation of the Action } \\
\text { Plan }\end{array}$ & 2 Sept-30Sept 2017 & \\
\hline 7 & Observation & 2 Sept-30Sept 2017 & \\
\hline 8 & Reflection & 2 Sept-30Sept 2017 & \\
\hline $\begin{array}{c}9 \\
10 \\
11\end{array}$ & $\begin{array}{l}\text { Drafting of Research Drafts } \\
\text { Draft Improvement } \\
\text { Finishing }\end{array}$ & $\begin{array}{l}03 \text { Oct } 2017 \\
04 \text { Oct } 2017 \\
05-07 \text { Oct } 2017\end{array}$ & $\begin{array}{l}\text { Data Processing \& Report } \\
\text { Preparation }\end{array}$ \\
\hline
\end{tabular}

The data collection techniques in this study are as follows.

a) Pre-Test and Post-Test Assessment 
The form of the test used in this study was multiple choice, namely a question that asks respondents to choose the sentence or description that is closest to their opinions, feelings, judgments or position.

b) Note the results of reflection

Reflection notes were noted that are obtained from the results of reflections carried out through discussion activities between researchers and research partners (supervisors). The results of this reflection aside from being used as material in the preparation of the next action plan can also be used as a means to find out whether or not the objectives of this research activity have been achieved (Permatasari, 2014).

In accordance with the data collection techniques mentioned above, the research instruments used in this PTS were questions about pre-test, post test questions, sheets / observation instruments. The analysis or discussion of data in PTS was done from the start, meaning that data analysis was done step by step or cycle by cycle. The phase of selection and data collection, the stage of presentation and description of data, and the stage of conclusions through reflection notes, namely thoughts that arise when observing and are the results of the process of comparing, linking or connecting data displayed with previous data or with theories that relevant (Daryanto, 2011).

In this PTS, the design of the action taken was training in the form of workshops that were attended by all teachers and guidance activities in direct practice in the classroom (specifically carried out for 14 teachers who are the subjects of research). In detail the actions taken were as follows:

1. Observe the implementation of the In House Training and conduct an evaluation (monev).

2. Guiding teachers to make teaching preparation (RPP) based on Learning Model Contextual Teaching and Learning. In this PTS all existing teachers are the subject of research.

3. Observing teacher activities in carrying out learning activities based on Learning Model Contextual Teaching and Learning.

4. Hold reflections (discussions between researchers / principals and teachers observed) about the advantages and disadvantages of learning activities based on the Learning Model Contextual Teaching and Learning that has been implemented and try to make formulas for the implementation of the next cycle. (Raka Joni, 2005)

\section{Results and Discussion}

Questionnaire Results of Participants' Response to In House Training Activities The Recap of the Participant's Questionnaire Results Response to the In House Training Activities can be seen in Table 2. 
Table 2. Recap of Participant Response Questionnaire Results

\begin{tabular}{|c|c|c|c|c|c|c|}
\hline No. & Statement of Participants & $\begin{array}{l}\text { Very } \\
\text { good }\end{array}$ & Well & Is being & Less & Total \\
\hline & Speaker & & & & & \\
\hline 1 & Over matter & 6 & 8 & 0 & 0 & 14 \\
\hline 2 & How to present material & 5 & 8 & 1 & 0 & 14 \\
\hline 3 & Motivate & 5 & 8 & 1 & 0 & 14 \\
\hline 4 & On time & 7 & 5 & 2 & 0 & 14 \\
\hline 5 & Explanation & 3 & 9 & 2 & 0 & 14 \\
\hline \multirow[t]{5}{*}{6} & Give an opportunity for discussion & 7 & 6 & 0 & 1 & 14 \\
\hline & Sub 1 score & 33 & 44 & 6 & 1 & 84 \\
\hline & Maximum score & 84 & 84 & 84 & 84 & 84 \\
\hline & $\begin{array}{c}\text { Results (acquisition score / max } \\
\text { score } \mathrm{x} 100 \% \text { ) }\end{array}$ & $39 \%$ & $52 \%$ & $7 \%$ & $1 \%$ & $100 \%$ \\
\hline & Material & & & & & \\
\hline 7 & The goal & 10 & 4 & 0 & 0 & 14 \\
\hline 8 & Relevant to the teacher's assignment & 9 & 4 & 1 & 0 & 14 \\
\hline 9 & Benefits of training activities & 12 & 2 & 0 & 0 & 14 \\
\hline 10 & In accordance with my wishes & 5 & 7 & 2 & 0 & 14 \\
\hline 11 & $\begin{array}{l}\text { In accordance with the demands of } \\
\text { the KTSP curriculum }\end{array}$ & 8 & 4 & 2 & 0 & 14 \\
\hline \multirow[t]{5}{*}{12} & The material is interesting & 6 & 8 & 0 & 0 & 14 \\
\hline & Score of sub 2 & 50 & 29 & 5 & 0 & 84 \\
\hline & Maximum score & 84 & 84 & 84 & 84 & 84 \\
\hline & $\begin{array}{l}\text { Results (acquisition score / max } \\
\text { score x 100\%) }\end{array}$ & $60 \%$ & $35 \%$ & $6 \%$ & $0 \%$ & $100 \%$ \\
\hline & Atmosphere & & & & & \\
\hline 13 & Lots of discussion & 9 & 3 & 2 & 0 & 14 \\
\hline 14 & $\begin{array}{l}\text { Active In House Training } \\
\text { participants }\end{array}$ & 6 & 6 & 2 & 0 & 14 \\
\hline 15 & $\begin{array}{l}\text { Implementation of activities for } \\
\text { improving competence }\end{array}$ & 6 & 7 & 1 & 0 & 14 \\
\hline 16 & $\begin{array}{l}\text { Knowledge of learning Contextual } \\
\text { Teaching And Learning Models }\end{array}$ & 6 & 7 & 0 & 1 & 14 \\
\hline 17 & Retention of material & 10 & 4 & 0 & 0 & 14 \\
\hline 18 & enthusiastic participants & 9 & 5 & 0 & 0 & 14 \\
\hline \multirow[t]{8}{*}{19} & $\begin{array}{l}\text { The work produced after the } \\
\text { training }\end{array}$ & 4 & 10 & 0 & 0 & 14 \\
\hline & Score of sub 3 & 41 & 39 & 3 & 1 & 98 \\
\hline & Maximum score & 98 & 98 & 98 & 98 & 98 \\
\hline & $\begin{array}{l}\text { Results (acquisition score / max } \\
\text { score } \mathrm{x} 100 \% \text { ) }\end{array}$ & $42 \%$ & $40 \%$ & $3 \%$ & $1 \%$ & $100 \%$ \\
\hline & Criteria & SB & B & $\mathbf{S}$ & $\mathbf{K}$ & Jlh \\
\hline & Amount Sub 1-3 & 124 & 112 & 14 & 2 & 266 \\
\hline & Maximum score amount & 266 & 266 & 266 & 266 & 266 \\
\hline & Percentage & $47 \%$ & $42 \%$ & $5 \%$ & $1 \%$ & $100 \%$ \\
\hline
\end{tabular}

Information

$\begin{array}{ll}\text { Very good } & 47 \% \\ \text { Well } & 42 \% \\ \text { Is being } & 5 \% \\ \text { Less } & 1 \%\end{array}$

(Trianto, 2007) 
Based on the results in Table 1, the tutor who carried out the In House Training activities in presenting the material based on the participant's assessment of the questionnaire distributed received positive response to the material presentation criteria, $39 \%$ of participants stated (very well), $52 \%$ of participants stated (Good), $7 \%$ of participants stated (moderate), and $1 \%$ of participants stated (less). The tutor always provide motivation to In House Training participants, available time needed to explain In House Training material. The use of CTL Models can be accepted by participants and presenters providing opportunities for In House Training participants for discussion.

For the material provided, $60 \%$ of participants stated very well, $35 \%$ of participants stated well, $6 \%$ of participants stated moderate, and $0 \%$ of participants stated less. The activities have a clear purpose for teachers, In House Training activities are relevant to teacher competency, usefulness of In House Training activities, In House Training activities are in accordance with the wishes of participants, the material presented by the tutor is in accordance with the K13 curriculum demands.

The atmosphere of the In House Training activities, $42 \%$ percent stated very well, $40 \%$ of participants stated well, $3 \%$ of participants stated moderate, and $1 \%$ of participants stated less. The active participants followed it, the implementation of activities for improving teacher competency, and participants basically already had knowledge of IT, the material delivered by the tutor was accepted by the participants and enthusiastic about following it, and the results produced by each participant felt the benefits after the In House Training activities.

\section{Cycle 1}

a) Results of Cycle 1 Teacher Practice

Recapitulation of teacher practice results in Using Learning Models Contextual Teaching and Learning through In House Training can be seen in Table 3.

Table 3. Results of Cycle 1 Teacher Practices

\begin{tabular}{|c|c|c|c|c|c|}
\hline \multirow{2}{*}{ No } & \multirow{2}{*}{ Subject teachers } & \multicolumn{4}{|c|}{ Cycle I Results } \\
\hline & & 1)* & Criteria & 2) ${ }^{*}$ & Criteria \\
\hline 1 & IPS & $88,64 \%$ & BS & $86,76 \%$ & $\begin{array}{c}\text { BS } \\
\text { (Enough) }\end{array}$ \\
\hline 2 & PKN & $77,27 \%$ & B & $67,50 \%$ & $\begin{array}{c}\text { Pendampingan } \\
\text { Cycle } 2\end{array}$ \\
\hline 3 & Matematika & $90,10 \%$ & BS & $85,83 \%$ & $\begin{array}{c}\text { B } \\
\text { (Enough) }\end{array}$ \\
\hline 4 & IPA & $72,72 \%$ & B & $66,37 \%$ & $\begin{array}{c}\text { Pendampingan } \\
\text { Cycle } 2\end{array}$ \\
\hline 5 & PJOK & $88,63 \%$ & BS & $74,17 \%$ & B \\
\hline 6 & Bahasa Indonesia & $88,63 \%$ & BS & $71,67 \%$ & B \\
\hline 7 & Bahasa Inggris & $90,00 \%$ & BS & $76,00 \%$ & B \\
\hline 8 & IPA & $84,09 \%$ & B & $74,17 \%$ & B \\
\hline 9 & Bahasa Inggris & $90,90 \%$ & BS & $77,50 \%$ & $\begin{array}{c}\text { B } \\
\text { (Enough) }\end{array}$ \\
\hline 10 & Bahasa Indonesia & $72,72 \%$ & B & $68,33 \%$ & $\begin{array}{c}\text { Pendampingan } \\
\text { Cycle } 2\end{array}$ \\
\hline
\end{tabular}




\begin{tabular}{|c|c|c|c|c|c|}
\hline 11 & Agama Kristen & $86,36 \%$ & BS & $77,50 \%$ & B \\
\hline 12 & $\mathrm{BK}$ & 0 & - & 0 & Sick \\
\hline 13 & Agama Islam & $75 \%$ & $\mathrm{~B}$ & $77,67 \%$ & B \\
\hline \multirow[t]{2}{*}{14} & Matematika & $84,09 \%$ & B & $77,94 \%$ & B \\
\hline & Average & $70,75 \%$ & & $75,49 \%$ & \\
\hline \multicolumn{6}{|c|}{ Information } \\
\hline \multicolumn{6}{|c|}{ Activities: 1)* Learning Planning, 2)* Observation of Learning Classes Contextual Teaching And } \\
\hline \multicolumn{6}{|c|}{ Learning Models. } \\
\hline \multicolumn{6}{|c|}{ A : Very good : $86 \%-100 \%$} \\
\hline \multicolumn{6}{|c|}{ B : Good : $70 \%-85 \%$} \\
\hline \multicolumn{6}{|c|}{ C : Enough : $55 \%-69 \%$} \\
\hline \multicolumn{6}{|c|}{ D : Less : Below $55 \%$} \\
\hline
\end{tabular}

The success of the teacher in implementing the CTL model in the classroom can be seen from the ability of 13 teachers who practice in the classroom. From the table 3 , it can be seen that there are 3 teachers who still have not demonstrated the ability to use the CTL model. The teacher gets an average 'enough' in carrying out the practice of CTL in the classroom. Realizing the above conditions, the teachers were pleased to improve their performance through mentoring activities by principals and senior teachers so that their performances could reach the "better" category. The average teacher's ability to prepare RPP for the CTL model is $70.75 \%$, (Category B), while the average teacher's ability to use the learning model CTL in class is $75.49 \%$ (Category B). For teachers who have the result of "sufficient" position, mentoring is carried out in cycle 2 along with teachers who have not practiced it, to achieve the value of "good" or "very good" means that the teacher must fully understand using the CTL Model. The next cycle activity is held on the 3rd week of September 2017.

b) Reflection

In this cycle 1 of the In House Training activity, the Tualang SMP 6 School Principal was assisted by a senior teacher. This does not reduce the meaning and purpose to be achieved, so that the teachers can add knowledge in making Learning Scenarios (RPP) regarding CTL Models and use them in their teaching.

c) Pretest results of the teacher

The results of conceptual understanding (Pre-test) of teachers of public junior high school 6 Tualang about the Learning Model Contextual Teaching and Learning can be seen in Table 4 .

The learning process carried out by the teacher must have an impact on the changes in attitudes and cognitive of students towards a better one. To achieve a good quality process, the teacher must be able to implement a variety of learning methods so that students achieve maximum competence. Learning Contextual Teaching and Learning Model is one of the learning models that is a concept that helps teachers associate the material taught with real world situations, trains students to think critically and creatively, this is very much in line with the demands of curriculum 13 (Kokom, 2012). 
Table 4. Recap of teacher's Pre-test Assessment Results in understanding the Contextual Teaching and Learning model

\begin{tabular}{llccc}
\hline No. & Name of Participant & $\begin{array}{c}\text { Correct } \\
\text { Number of } \\
\text { Answers }\end{array}$ & $\begin{array}{c}\text { Amount of } \\
\text { Wrong } \\
\text { Answers }\end{array}$ & $\begin{array}{c}\text { Understanding } \\
\text { Percentage }\end{array}$ \\
\hline 1 & Guru Mapel IPS & 8 & 7 & $53 \%$ \\
2 & Guru Mapel PKN & 5 & 10 & $33 \%$ \\
3 & Guru Mapel Matematika & 11 & 4 & $73 \%$ \\
4 & Guru Mapel IPA & 7 & 8 & $47 \%$ \\
5 & Guru Mapel PJOK & 10 & 5 & $67 \%$ \\
6 & Guru Mapel B.Indonesia & 5 & 10 & $33 \%$ \\
7 & Guru Mapel B. Inggris & 8 & 7 & $53 \%$ \\
8 & Guru Mapel B. Inggris & 9 & 6 & $60 \%$ \\
9 & Guru Mapel B.Indonesia & 7 & 9 & $47 \%$ \\
10 & Guru Mapel IPA & 12 & 8 & $80 \%$ \\
11 & Guru Mapel Matematika & 9 & 6 & $60 \%$ \\
12 & Guru Mapel BK & 7 & 8 & $47 \%$ \\
13 & Guru Mapel Agama & 7 & 8 & $47 \%$ \\
14 & Guru Mapel Agama Kristen & 5 & 10 & $33 \%$ \\
\hline \multicolumn{7}{r}{} & Total of answers & $\mathbf{1 1 0}$ & $\mathbf{1 0 6}$ & $\mathbf{2 1 6}$ \\
\hline
\end{tabular}

Description of Problem Weight

$>$ If it is correct 1 value $1>$ If true 0 value is $0>$ If 1 is a value of 0

Based on the recapitulation of the pre-test results that the initial teacher's ability to understand the learning concept of Contextual Teaching and Learning does not yet understand, it means that from 14 new teachers around 52\% are 7 teachers who understand the concept of learning Contextual Teaching and Learning and $49 \%$ of the other 7 teachers did not really understand the concept of Contextual Teaching and Learning even though there were actually those who had received training through the MGMP about learning methods.

Based on the data above, the researcher as the principal takes action by giving the opportunity to the teachers to improve their competence through In House Training using the CTL model in the second cycle.

\section{Cycle 2}

a) Results of Cycle 2 Teacher Practice

Recapitulation of the results of mentoring in the In House Training activities for teachers who have not reached the expected criteria and for teachers who have not yet practiced, can be seen in Table 5 .

From the data in Table 5, recapitulation of the results of mentoring in Cycle 2, shows that the success of the teacher in implementing the CTL model in the class from the ability of 3 teachers who practice in the classroom is as follows: 3 teachers who get "good" scores, and there is no teacher who gets an "adequate" score in carrying out the practice in class. Meanwhile, there were 3 teachers who were able to plan learning with a value of "very good" and 1 person was absent because of illness. The average ability of teachers to prepare lesson plans in Cycle 2 is $90.58 \%$, 
(SB category) while the average ability of practice teachers uses learning models in the class of $82.35 \%$ (Category B).

Table 5. Results of Teacher Practice in Cycle 2

\begin{tabular}{|c|c|c|c|c|c|c|}
\hline \multirow[b]{2}{*}{ No } & \multirow{2}{*}{$\begin{array}{l}\text { Subject } \\
\text { teachers }\end{array}$} & \multicolumn{4}{|c|}{ Cycle 2 Results } & \multirow[t]{2}{*}{ Follow-up } \\
\hline & & 1) ${ }^{*}$ & Follow-up & 2)* & Criteria & \\
\hline 1 & PKN & $88,64 \%$ & BS & $82,35 \%$ & B & \\
\hline 2 & IPA & $90,10 \%$ & BS & $85,50 \%$ & B & \\
\hline 3 & $\mathrm{BK}$ & - & - & - & - & \\
\hline 4 & Bahasa & $93 \%$ & BS & $79,20 \%$ & & \\
\hline & Indonesia & & & & B & \\
\hline Average & & $90,58 \%$ & & $82,35 \%$ & & \\
\hline
\end{tabular}

Information:

Activities: 1)* Learning Planning, 2)* Observation of the Implementation of Teaching Teachers using the Contextual Teaching and Learning Model.

A : Very good : 86\%-100\% B : Good : 70\%-85\% C : Enough : 55\%-69\% D : Less : Below 55\%

\section{b) Reflection}

The personal approach that has been done, generally the teachers of SMPN 6 Tualang did not experience difficulties in creating learning scenarios for the Contextual Teaching and Learning model. This can be seen from the results of the planning assessment (RPP) which have a good average. As input from the teachers that this activity was very positive for them and the participants suggested that in the future there would be another training for other learning models.

c) Postest results of the teacher in understanding the Contextual Teaching and Learning model

The results of the recapitulation of the development of the understanding of the concepts of each teacher before and after the In House Training activities using the Contextual Teaching and Learning learning model can be seen in Table 6 .

Table 6. Comparison of the results of the teacher's pre-test and post-test

\begin{tabular}{ccccc}
\hline \multirow{2}{*}{ No. } & \multirow{2}{*}{ Subject teachers } & \multicolumn{2}{c}{ Test Results (\%) } & \multirow{2}{*}{ Increase } \\
\cline { 3 - 4 } & & Pre-test & Post-test & \\
\hline 1 & IPS & $53 \%$ & $100 \%$ & $47 \%$ \\
2 & PKN & $33 \%$ & $73 \%$ & $40 \%$ \\
3 & Matematika & $73 \%$ & $100 \%$ & $27 \%$ \\
4 & IPA & $47 \%$ & $87 \%$ & $40 \%$ \\
5 & PJOK & $67 \%$ & $93 \%$ & $26 \%$ \\
6 & Bahasa Indonesia & $33 \%$ & $87 \%$ & $54 \%$ \\
7 & Bahasa Inggris & $53 \%$ & $93 \%$ & $40 \%$ \\
8 & IPA & $80 \%$ & $93 \%$ & $13 \%$ \\
9 & Bahasa Inggris & $60 \%$ & $100 \%$ & $40 \%$ \\
10 & Bahasa Indonesia & $47 \%$ & $87 \%$ & $40 \%$ \\
11 & Agama Kristen & $33 \%$ & $73 \%$ & $40 \%$ \\
12 & BK & $47 \%$ & - & - \\
13 & Agama Islam & $47 \%$ & $80 \%$ & $33 \%$ \\
14 & Matematika & $60 \%$ & $93 \%$ & $33 \%$ \\
\hline & Average & $\mathbf{5 2 \%}$ & $\mathbf{8 9 \%}$ & $\mathbf{3 7 \%}$ \\
\hline
\end{tabular}


The results of the development of changes in teacher understanding can be seen from the results of pre-tests and post-tests carried out in the In House Training activities. It can be seen that the percentage change rate averaged $37 \%$. The results of the teaching teacher's practice using the learning model Contextual Teaching and Learning in Cycle 2 are on average "Good", there is no teacher who gets the "Sufficient" prediction value.

\section{Conclusion}

In the RPP design component the Contextual Teaching and Learning learning model shows a significant increase from cycle 1 to cycle 2 . In implementing real teaching using the Contextual Teaching and Learning learning model, there is also an increase in competence from cycle 1 to cycle 2 . Increased understanding of the components of making lesson plans for the Contextual Teaching and Learning model (specifically for 3 teachers) from the "Good" category in cycle 1 to "Very Good" in cycle 2. Likewise in the real teaching component of the 3 teachers, from predetition "Enough" in cycle 1 becomes a prediction of "Good" in cycle 2. In the Component of Conceptual Understanding Contextual Teaching and Learning Learning Models, there is an increase in conceptual understanding in the post-test. From the acquisition of research data in this school action research activity, it can be concluded that the improvement of teacher competencies using the learning model Contextual Teaching and Learning through In House Training at Tualang State Junior High School 6 conducted by the principal of 13 teachers, has succeeded in increasing their competence in compile RPP learning models Contextual Teaching and Learning and in the implementation of real teaching.

\section{References}

Daryanto. (2011). Penelitian Tindakan Kelas Dan Penelitian Tindakan Sekolah: Beserta contoh-contohnya. Yogyakarta: Penerbit Gava Media.

Depdiknas. (2007). Pedoman Penilaian Hasil Belajar di Sekolah Dasar. Jakarta: Dirjen Manajemen SD dan Menengah

Faddilaturrahmi. (2016). Peningkatan Hasil Belajar Siswa Pada Materi Jaringjaring Balok dan Kubus dengan Pendekatan CTL siswa Kelas IV SDN 05 Air Tawar Barat. Jurnal Basicedu, 1(1), 1-9.

Fakhruddin, z., Lilia, H., \& T. Subahan Mohd, H. (2017). Practicality Assesment of Student Worksheets for SMP Physics Learning on the Traditional Culture-Based Equipment. Journal of Educational Sciences, 1(1), 65-78.

Hudson, C. C., \& Whisler, V. R. (2013). Contextual teaching and learning for practitioners. Systemics, Cybernetics and Informatics, Vol. 6 No.(4), 5458.

Kokom, K. (2012). The Effect Of Contextual Learning In Civic Education On Students' Character Development. Asia Pacific Journal of Educators and Education, 27 (1), 87-103.

Leonard. (2013). Peran Kemampuan Berpikir Lateral dan Positif Terhadap Prestasi Belajar Evaluasi Pendidikan. Cakrawala Pendidikan, XXXII (1), 54-63. 
NCTM. (2000). Principles and Standards For School Mathematics. Reston, Virginia, The National Council Of Teachers Of Mathematics. Inc.

Nurhadi. (2003). Pembelajaran Kontekstual (Contextual Teaching and Learning) dan Penerapannya dalam KBK. Malang: Universitas Negeri Malang.

Peraturan Menteri Pendidikan dan Kebudayaan No. 22 Tahun 2016 tentang Standar Proses Pendidikan Dasar dan Menengah. Jakarta: Depdiknas.

Permatasari, E. A. (2014). Implementasi pendekatan saintifik dalam kurikulum 2013. Indonesian. Journal of History education, 3 (1), 11-16.

Joni, R. (2005). Pembelajaran yang Mendidik: Artikulasi Konseptual, Terapan Kontekstual dan Verifikasi Empirik. Jurnal Ilmu Pendidikan, 12 (2), 5666.

Sanjaya,W. (2009). Penelitian Tindakan Kelas. Jakarta: Kencana, Prenada Media Group.

Scholaria. (2016). Implementasi TQM melalui pelatihan model IHT untuk meningkatkan kompetensi pedagogik guru SD. Jurnal Pendidikan dan Kebudayaan, 6 (2), 12-21.

Trianto. (2007). Mendesain Pembelajaran Kontekstual (Contextual Teaching and Learning) di Kelas. Jakarta: Cerdas Pustaka Publiser.

How to cite this article:

Suhelmidam (2019). Improvement of Teacher Capability Using Contextual Teaching and Learning Learning Models Through in House Training at State 6 Tualang High School. Journal of Educational Sciences, 3(3), 281-291. 